\title{
The Impact of Option Listing on the Trading Activity of Turkcell's American Depository Receipt (ADR)*
}

\author{
Aslı Aşçığlu** \\ Bryant University
}

\author{
Murat Aydoğdu*** \\ Rhode Island College
}

\author{
Lynn Phillips Kugele**** \\ The University of Mississippi
}

\begin{abstract}
We investigate the impact of the introduction of options on the market microstructure aspects of the NYSE-traded Turkcell İletişim Hizmetleri A.Ş., (Turkcell) ADR by studying changes in fundamental market liquidity metrics before and after the option (TKC) listing. We find that both daily relative quoted spreads and daily effective spreads decrease after the option introduction. Additionally, we show that the number of trades increases statistically significantly, while volatility, trade size and trading volume show no statistically significant change. We conclude that the introduction of options has a positive impact on the trading of the underlying asset, Turkcell's ADR, reducing trading costs significantly while increasing liquidity.
\end{abstract}

Keywords: option listing, liquidity, trading costs, Turkcell Iletisim Hizmetleri A. Ş.,Turkcell ADR

JEL Classifications: G10, G15, G14.

\section{Turkcell Amerikan Depo Sertifikası (ADR) Opsiyonunun Borsaya Kaydedilmesinin Turkcell ADR Piyasa Hareketleri Üzerine Etkisi}

\section{Özet}

Bu çalışma Turkcell İletişim Hizmetleri A.Ş. (Turkcell) ADR opsiyonunun New York Borsası'na kaydedilmesinin, Turkcell ADR piyasa yapısı üzerindeki etkisini incelemektedir. Yaptığımız çalışmada günlük piyasa alış-satış fiyatları arasındaki farkın ve günlük efektif alış-satış fiyatlari arasindaki farkın opsiyonun borsaya kaydedilmesi sonrası azaldığını bulmaktayız. Bunlara ek olarak, toplam günlük işlem adedinin istatistiksel açıdan anlamlı olarak arttığını ancak volatilite, işlem büyüklüğü ve işlem

\footnotetext{
* The authors thank Sam Agyei-Ampomah for his insightful comments and participants of the Multinational Society Annual Meeting 2010 for their helpful discussions. Comments and suggestions from an anonymous referee on an earlier version of this manuscript are gratefully acknowledged. Any errors are the responsibility of the authors.

** Aslı Aşçığlu is a Professor in the Department of Finance at Bryant University, 1150 Douglas Pike, Smithfield, RI 02917-1284, U.S.A. E-mail: ascioglu@bryant.edu.

*** Murat Aydoğdu is an Associate Professor in in the School of Management at Rhode Island College, 600 Mount Pleasant Avenue, Providence, RI 12908-1991, U.S.A. E-mail: maydogdu@ric.edu

**** Lynn Phillips Kugele is a Clinical Assistant Professor in the Department of Finance at The University of Mississippi, 5107 W.E. Ross. Parkway, Southaven, MS 38671, U.S.A. E-mail: lpkugele@olemiss.edu
} 
hacminin değişmediğini göstermekteyiz. Sonuçlar, Turkcell ADR opsiyonunun New York Borsası'na kaydedilmesinin, Turkcell ADR piyasa yapısını olumlu etkileyerek işlem maliyetlerini azalttığını ve likiditeyi arttırdığını desteklemektedir.

Anahtar kelimeler: opsiyon borsa kaydl, piyasa likiditesi, Turkcell Iletisim Hizmetleri A. Ş, Turkcell ADR JEL Sinıflandirması: G10, G15, G14.

$\mathrm{T}$ Turkcell İletişim Hizmetleri A.Ş., (Turkcell from here forward) is a Turkish-based, mobile telecommunications company established in 1994. Turkcell became a publicly traded company on July 11, 2000 by listing its common stock on the Istanbul Stock Exchange (İstanbul Menkul Kiymetler Borsası, or İMKB) under the ticker symbol TKCELL. Turkcell simultaneously listed on the New York Stock Exchange as an ADR (NYSE, ticker symbol: TKC), becoming the first Turkish company traded on the NYSE. While TKCELL is one of the most actively traded securities on the IMKB, TKC is traded only moderately on the NYSE. On December 22, 2005, the Pacific Stock Exchange ${ }^{[1]}$ introduced options on Turkcell's ADR, an especially significant event as there is no established option market in Turkey.

The existence of Turkcell common stock shares, ADRs and options on the ADR provides a unique opportunity to further investigate the impact of option introduction on the asset underlying the option (the ADR) as a proxy for the primary underlying asset, Turkcell shares. Further, the structure of the trading venues involved and the specific trading characteristics of the two underlying securities are sufficiently different to offer the possibility that the effects of option introduction may well differ from conventional expectations.

In this study, we analyze the impact of the introduction of TKC options on the market microstructure aspects of the NYSE-traded ADR by studying changes in metrics measuring three fundamental market liquidity variables before and after TKC's option listing: the bid-ask spread, trade volume and return volatility. In studying the bid-ask spread, we utilize both the quoted and effective spread in our analysis. Trade volume is examined using number of trades, share volume and trade size. We find that both daily relative quoted spreads and daily effective spreads decrease after the option introduction. Additionally, we show that the number of trades increases statistically significantly, while the volatility, the trade size and the trading volume show no statistically significant change. We conclude that the introduction of options on TKC has a positive impact on the trading of TKC, Turkcell's ADR, reducing trading costs while increasing liquidity.

We believe that these results are indicative of and consistent with expectations regarding the impact on equity trading of the options market in Turkey. Derivatives trading has a very short history in Turkey, with TURKDEX, the Turkish Derivatives Exchange trading futures contracts established in 2001. A Turkish equity options market has yet to come to fruition. It is generally agreed that derivative markets "allow traders to bet-

[1] The Pacific Stock Exchange was acquired in 2005 by the New York Stock Exchange via its purchase of ArcaEx. 
ter shape the risk and return characteristics of their portfolios, thereby increasing their welfare and enriching the economy in which they operate" (Kalib, 1999: 6)

According to Saatçioğlu, Karagül and Volkan (2005), markets that provide a venue for active trading in derivative products attract a larger share of total global foreign direct investment than those with no active derivatives markets.

Turkish companies are increasingly influenced by global financial developments, increasing the need for risk management tools. Saatçioğlu, et al. conclude that this results in the need for the establishment of active derivatives exchanges in Turkey, trading both futures and option contracts.

Saatçioğlu, Karagül and Volkan (2005) expect the following impacts on Turkish markets when there is stock option trading in Turkey:

- Reduced volatility of returns

- Enhanced professional reputation for Turkish capital markets in the international arena.

- Increased stock trading volumes.

- Improved stock market efficiency and liquidity.

- An improved price-adjustment process.

- Significantly decreased bid-ask spreads.

- Availability of risk diversification avenues for fund and portfolio managers.

- Provision of "a high comfort level to foreign investors who wish to trade in Turkish stock options, leading to an increase in long-run and/or permanent foreign direct and portfolio investments flowing into Turkey" (Saatçioğlu, Karagül and Volkan, 2005: 44).

Given the solid evidence supporting the benefits accruing to markets implementing trading in stock options, we believe our results, though limited to trading in one option, can be extrapolated to support the positive impact stock options trading will have on related equity market efficiency in Turkey as well as attracting more foreign investment to the country.

\section{Background}

\section{Trading Characteristics}

The New York Stock Exchange is a highly liquid auction market with the majority of trades occurring between actual buyers and sellers. Each listed firm has a single designated market-maker, the specialist, who is charged with overseeing all trading in that firm's stock. The specialists' obligations include maintaining two-sided quotes and generally insuring an orderly market in the firm's stock. Priced orders (limit orders to buy or sell shares at a specific price) are recorded in the specialists' limit order book. Incoming market orders may be executed against an existing limit order, with a floor trader or against the specialists' own quotes. Orders are filled at either the best available price (highest bid/lowest ask) or at a price inside the quotes, known as "price improvement," an event reported to occur $25 \%$ of the time. 
In contrast, the Istanbul Stock Exchange (İMKB) is a very active but highly volatile market with over $50 \%$ of listed shares owned by foreign and international institutional investors. The İMKB is a computerized, order-driven market with no market-makers or specialists and no opening call procedures for either its morning or afternoon sessions (9:30 am to 12 noon and 2:00 pm to 4:30 pm respectively). A distinct feature of the IMKB is that during trading hours, order cancellation or change is deemed "almost impossible," a restriction designed to improve quoted depth and avoid sudden liquidity shifts during the trading day. In addition, due to the institutional structure of the IMKB, "price improvement" or trades occurring inside the quotes, a major attraction of the New York Stock Exchange, is not possible on the İMKB.

Typical studies of the effects of option introduction focus on the impact on the underlying security which is usually an actively traded common stock. In our study, the underlying security is a moderately traded ADR rather than the true primary asset, Turkcell common shares.

\section{Overall Effects of Option Listings}

Literature on the impact of options listings generally agrees that the introduction of options serves to complete the market for the underlying security, expanding the opportunity set for investors. This case is made by many researchers, among them Breeden and Litzenberger (1978), Hakansson (1978), Arditti and John (1980), John (1981), Damodaran and Lim (1991), Fedenia and Grammatikos (1992), Sahlström (2001), and Saatçioğlu, Karagül and Volkan (2005). Typical explanations center around increases in liquidity, reductions in information asymmetry and greater pricing efficiency as a result of options listing, with these results driven primarily by changes in the bid-ask spread, volatility and trading volume.

In explaining these changes, Fedenia and Grammatikos (1992) and Sahlström (2001) suggest that options may allow traders to avoid short sale constraints, allowing market participants more freedom to profit from private information. Several researchers suggest that informed traders, viewing options as superior speculative instruments, may migrate to the options market, reducing the level of informed trading in the underlying asset. A lower probability of trading against information drives a reduction in the adverse selection component of the stock's bid-ask spread and potentially higher liquidity.

In somewhat contrary findings, DeTemple and Jorion (1991) find that the stock prices of assets underlying recently listed options increased through 1980 but this effect underwent a shift in 1981, with prices exhibiting decreases thereafter. Their results are consistent with those of Conrad (1989), Kabir (1999) and Mayhew and Mihov (2000) who find stock price increases up to 1980. Sorescu (2000) and Danielsen and Sorescu (2001) also confirm that the pre-1981 stock price increases yet price decreases after 1981 . DeTemple and Jorion suggest that this regime shift may be attributed to the introduction of index options in 1982 which serve the purpose of "completing the market" thus reducing the need for individual stock options to serve this purpose. While this may be a contributing factor in the market impact of options on U.S. stocks, we believe that the effect will be muted for an ADR based on a Turkish stock since, at the time of the 
TKC option listing, there was no index option based on the Turkish market index. The iShares MSCI Turkey Investable Market Index Fund was introduced on March 26, 2008.

With such strong and overall consistent previous results, we expect the introduction of options on TKC to have a positive impact in the market for the ADR. In order to test our expectations, we focus on three metrics typically associated with market quality: the bid-ask spread, the volatility of stock returns, and trading volume.

\section{Hypothesis 1: Impact of Option Listing on the Bid-Ask Spread}

Previous research on the impact of options listing on the bid-ask spread of the underlying security consistently finds a decline in spread, driven primarily by a decrease in the adverse selection component. Skinner (1989), Damodaran and Lim (1991), Rao, Tripathy and Dukes (1991), Schultz and Zaman (1991), Fedenia and Grammatikos (1992), and Kim and Diltz (1999) studying U.S. markets concur in their findings that options introduction results in a decrease in the bid-ask spread of the underlying asset. Additionally, Sahlström (2001), investigating Finnish stocks, finds bid-ask spread levels are lower after the option listing, with the adverse selection component, as well as the order processing, inventory and holding components decreasing.

Kumar, Sarin and Shastri (KSS, 1998) are representative of these findings, reporting a decrease in the spread, driven by a reduction in the adverse selection component and persisting even after controlling for changes in trading volume, volatility and price.

Fedenia and Grammatikos (1992), however, qualify these overall results on the spread, finding that highly liquid (NYSE) stocks experience spread increases, while the bid-ask spread of illiquid (OTC) stocks tends to decrease.

While Turkcell shares are very actively traded on their home market, Turkcell's ADRs (TKC) and options are lightly traded on the NYSE. Thus, we expect the bid-ask spread of the ADRs on the NYSE [BAS(NYSE)] to respond to option introduction in a manner more in line with the OTC stocks in Fedenia and Grammatikos and thus to experience a decline.

$\mathbf{H}_{1}: B A S(N Y S E)$ decreases with the introduction of option trading.

\section{Hypothesis 2: Impact of Options Listing on the Volatility of the Returns on the Underlying Asset}

The effect of option listing on the volatility of the returns on the underlying asset is probably analyzed more than any other aspect of market impact. The results tend to be fairly conclusive, with researchers almost consistently reporting a decline in volatility after option listing. Hayes and Tennenbaum (1979), Whiteside, Duke, and Dunne (1983), Ma and Rao (1988), Bansal, Pruit and Wei (1989), Conrad (1989), Skinner (1989), DeTemple and Jorion (1990), Damodaran and Lim (1991), Rao, Tripathy, and Dukes (1991), and Schultz and Zaman (1991) find that stock return volatility in U.S. markets is lower after option introduction. Similar results are found by Watt, Yadav, and Draper (1992) studying the UK market, Chaudhury and Elfakhani (1995) investigating 
the Canadian market, Stucki and Wasserfallen (1994) the Swiss markets, Sahlström (2001) studying Finnish stocks, and Chen and Chang (2008) Taiwan.

Damodaran and Lim's (1991: 647) findings are representative of these results, reporting that "the listing of options leads to significantly lower (emphasis in the original) variance in the daily returns of the underlying stocks"

Conversely, Kabir (1997) studying the Dutch market, Calado, Garcia and Pereira (2005) studying Portuguese markets and Mazouz and Bowe (2009) studying NYSE stocks listed on the CBOE find no significant change in risk following option listing.

In much the spirit of Fedenia and Grammatikos's findings on the bid-ask spread, Ma and Rao (1988) qualify their results, suggesting that differences in trading patterns of uninformed and informed traders result in volatile stocks becoming more stable after option listing, while stable stocks become more volatile.

In line with Ma and Rao's findings combined with the relatively light trading of TKC on the NYSE, we expect the volatility of returns on the ADRs on the NYSE $[\sigma(\mathrm{NYSE})]$ to decrease:

$\mathbf{H}_{2}: \sigma$ (NYSE) decreases with the introduction of option trading.

\section{Hypothesis 3: Impact of Options Listing on Trading Volume of the Underlying Asset}

An increase in trading volume in the underlying asset following option listings in U.S. markets is reported by Hayes and Tennenbaum (1979), Skinner (1989), Schultz and Zaman (1991), Shastri, Sultan and Tandon (1996), Kumar, Sarin and Shastri (1998), and Jubinski and Tomijanovich (2007). Conversely, a decrease in volume is reported by Damodaran and Lim (1991) and no change in trading volume is documented by Whiteside, Dukes and Dunne (1983) and Chamberlin, Cheung, and Kwan (1993), the latter studying Canadian stocks. Heer, Trede, and Wahrenburg (1997) find an increase in volume in German markets, Chen and Chang (2008) report similar results in the Taiwan market as do Yip and Lai (2009), studying warrant listings in Malaysia.

Kumar, Sarin and Shastri (1998) specifically find an increase in trading volume, trading frequency, and transaction size after option listing, an effect which persists even after controlling for changes in volatility and price. They attribute the increase in trading volume to a combined effect of higher trading frequency and larger average transaction size.

In accord with previous research results, we expect trading liquidity measures, trading volume, trading frequency and the transaction size on the NYSE to increase [Liquidity(NYSE)]:

$\mathbf{H}_{3}$ : Liquidity (NYSE) increases with the introduction of option trading. 


\section{Data and Analysis}

\section{Data}

We obtain all quotes and transactions data from 60 business days before and 60 business days after the option listing day, December 22, 2005, for TKC from the NYSE Transaction and Quote (TAQ) database. We use the following filters:

a) Only BBO eligible NYSE quotes are retained.

b) Quotes and trades must have a time stamp between 9:30 am and 4:00 p.m.

c) Trade price must be $>0$

d) Ask price must be $>0$

e) Bid price must be $>0$

f) Trades must have a correction code value greater than or equal to one.

g) Pre-opening quotes are excluded.

\section{Analysis Methodology}

We measure the relative quoted spread as the difference between the bid and ask quotes scaled by the quote mid-point

$$
\text { Relative Quoted Spread }=\frac{\left(\text { Ask }_{t}-\text { Bid }_{t}\right)}{M_{t}}
$$

It is well established that the quoted spread overestimates the cost of transacting as it does not account for trades occurring at prices inside the quotes, a relatively common occurrence on the NYSE. For most orders executed on the New York Stock Exchange, the effective spread paid by investors averages half the quoted spread. Thus, we calculate the relative effective spread as follows:

$$
\text { Effective Spread }=2 *\left|\frac{P_{t}-M_{t}}{M_{t}}\right|
$$

where $P_{t}$ is the transaction price and $M_{t}$ is the midpoint of the matched quote. We also measure price improvement given by a specialist, as the difference between the relative quoted spread and the effective spread.

\section{Overall Analysis}

As a first test of our expectations, we average relative quoted spreads, effective spreads, price improvement, number of trades, trade size, trading volume and volatility for each day for 120 days around the option listing day.

We use a T-Test and a Wilcoxon Nonparametric Signed-Rank test to determine whether our liquidity measures are statistically different 60 days before and 60 days after the option listing. We expect to observe an increase in liquidity, the number of trades, average trade size and total trading volume, and a decrease in relative quoted spreads, effective spreads and volatility. 


\section{Specific Tests of Hypothesis 1: Impact on the Bid-Ask Spread}

We employ two regressions to determine whether percentage bid-ask spreads decrease due to the introduction of options trading after controlling for trading characteristics. Basically, we follow Kim and Diltz (1999), with the addition of four interaction terms to provide for finer tuning of the results. Furthermore, an event like option listing can alter the nature of the relationship between spread and the explanatory variables. Using interaction terms sheds light on whether the sensitivity of spread to the explanatory variables changes after the option listing. We divide each day into 30-minute 13 intervals, and measure all variables for 30-minute interval for each day. For the first regression, the quoted spread is the dependent variable:

$S_{P R}=\alpha+\beta_{1} D U M M Y_{t}+\beta_{2} L N T R A D E S_{t}+\beta_{3} L N V O L U M E_{t}+\beta_{4} S I G M A_{t}+\beta_{5} L N P R I C E_{t}$

+ INTTRDS $_{t}+$ INTVOL $_{t}+$ INTSIGMA $_{t}+I N T P R I C E_{t}+\varepsilon_{t}$

Where:

$S P R$ is the average relative quoted spread calculated as the difference of the bid and ask quotes scaled by the quote midpoint (Equation 1)

DUMMY is a dummy variable equal to zero for days prior to the option listing period and one otherwise.

LNTRADES is the natural log of total number of trades

LNVOLUME is the natural log of total trading volume

SIGMA is natural log of the difference between the percentage maximum midpoint quote price and the minimum midpoint quote price

LNPRICE is the natural log of average trading price

INTTRDS is the interaction variable for number of trades: DUMMY*LNTRADES

INTVOL is the interaction variable for trading volume: $D U M M Y^{*} L N V O L U M E$

INTSIGMA is the interaction variable for volatility: $D U M M Y^{*} S I G M A$

INTPRICE is the interaction variable for price: $D U M M Y * L N P R I C E$

The second regression uses the relative effective spread as the dependent variable with the same independent variables as described above.

EFFSPR $_{t}=\alpha+\beta_{1}$ DUMMY $_{t}+\beta_{2}$ LNTRADES $_{t}+\beta_{3}$ LNVOLUME $_{t}+\beta_{4}$ SIGMA $_{t}+$ $\beta_{5}$ LNPRICE $_{t}+\operatorname{INTTRDS}_{t}+$ INTVOL $_{t}+{I N T S I G M A_{t}}+I N T P R I C E_{t}+\varepsilon_{t}$

We expect a negative coefficient for the dummy variable if the spread is smaller following the option listing after controlling for other trading variables. We expect negative coefficients for both LNTRADES and LNVOLUME, indicating a reverse relationship between spreads and trading activity. ${ }^{[2]}$ We expect a positive coefficient

[2] McInish and Wood (1992) have a detailed discussion of determinants of spreads, and establish the relationship between spreads and other trading activities. 
for SIGMA consistent with McInish and Wood (1992), who find a direct relationship between the level of risk and spreads. Kim and Diltz (1998: 400) find "all of the regression coefficients for trading characteristics are statistically significant and consistent in sign with prior microstructure research." While the sign of the dummy variable is negative in their work, it is not statistically significant, leading them to inconclusive findings. We expect results consistent with Kim and Diltz, confirming a decrease in the bid-ask spread post listing.

In the case of both regressions, we approach the analysis in a three step manner. For each specification, the first regression (\#1) includes the dummy, number of trades and volume variables along with the number of trades and volume interaction terms. In the second iteration (\#2), we add volatility and the volatility interaction variable. In the final iteration (\#3), we add price and the price interaction variable.

\section{Results}

\section{Overall Results}

Table 1 displays the results of the T-tests and the Wilcoxon Nonparametric test on each of our variables of interest, comparing pre-listing averages to post-listing averages. The decreases in both relative spreads and effective spreads are statistically significant at the $1 \%$ level. The standard deviations of both spread metrics also decline after option listing indicating that not only do spreads decline but also become less volatile. The decline in price improvement is also significant at the $1 \%$ level. Since the effective spread decreases significantly from 0.1731 to 0.1489 , reducing the profit of a specialist (or a liquidity provider to the market), the price improvement a specialist is providing to other investors also declines As visual confirmation, Graph 1 shows both spread variables and price improvement for 120 days around the option listing day, illustrating the trend of decreasing spreads and price improvement after the listing. Therefore, we find evidence of decreasing transaction costs and support of Hypothesis 1.

Graph 1

Spreads

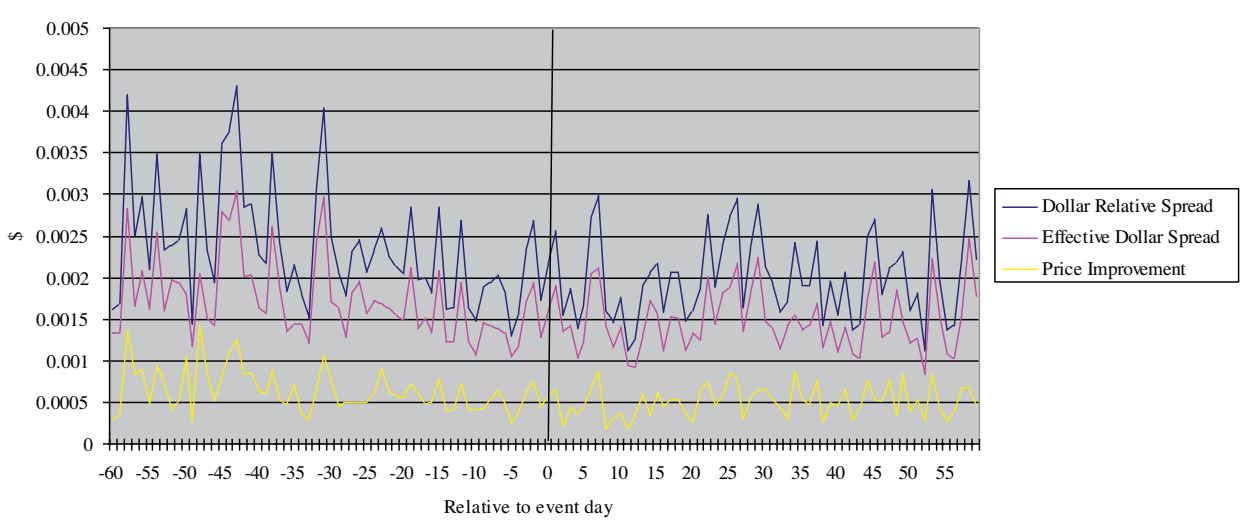




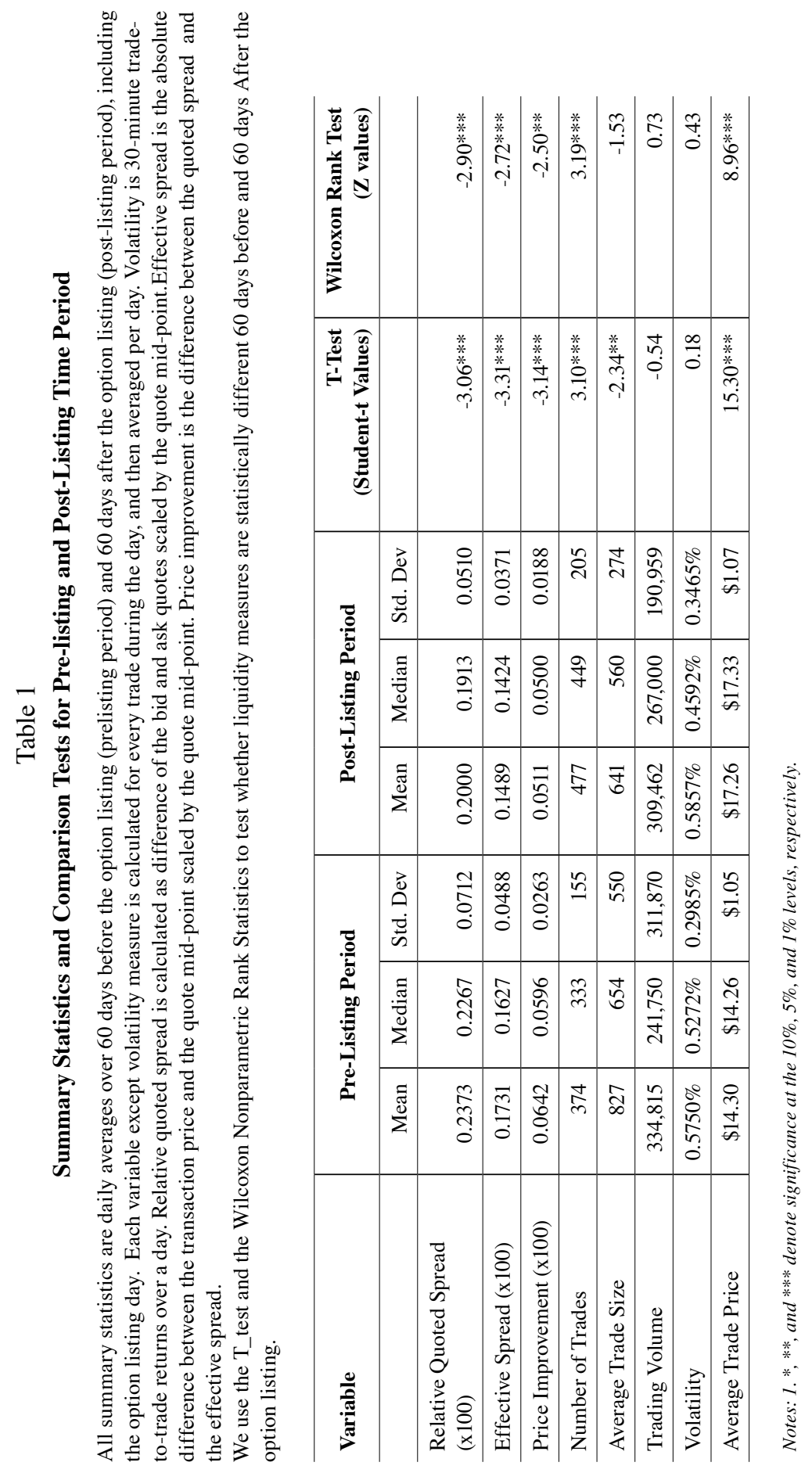


The risk measure, a standard deviation of 30-minute interval returns, shows no statistically significant change in Table 1. Therefore, we reject our Hypothesis 2 and do not find a decline in volatility after option listing. On the other hand, the median of volatility shows a decrease from $0.5272 \%$ to $0.4592 \%$ after the listing. This indicates that there are more days with less volatility after the option listing.

\section{Graph 2}

\section{Number of Trades}

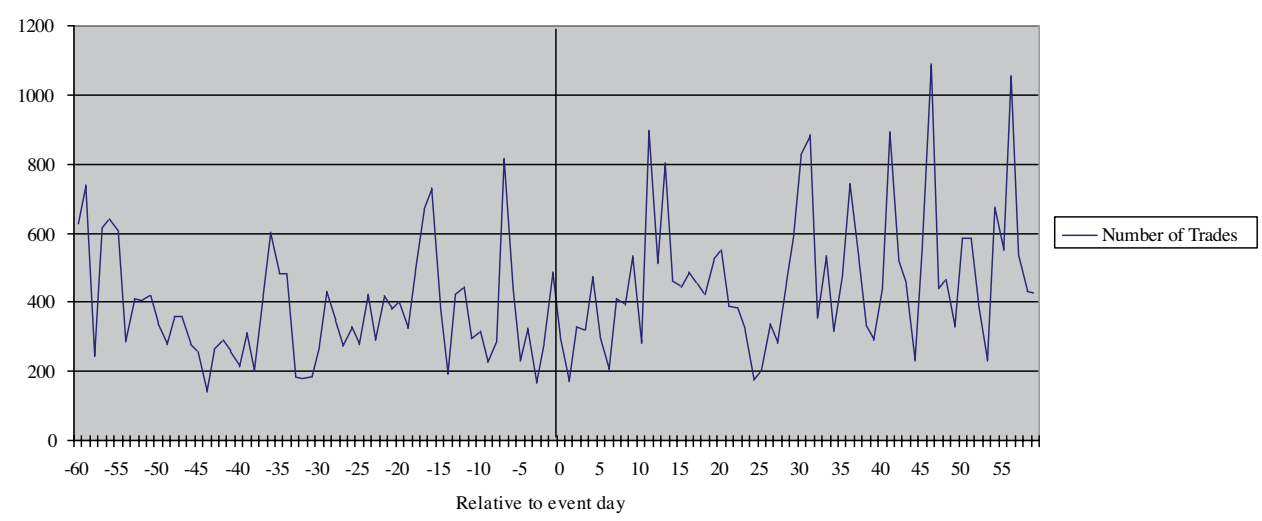

The three trading level metrics display conflicting results. Graph 2 clearly shows the increase in the number of trades around the option listing day. On the other hand, Graph 3 and Graph 4 visibly illustrate the decline in average trade size per day and daily total trading volume respectively.

\section{Graph 3}

\section{Average Trade Size}

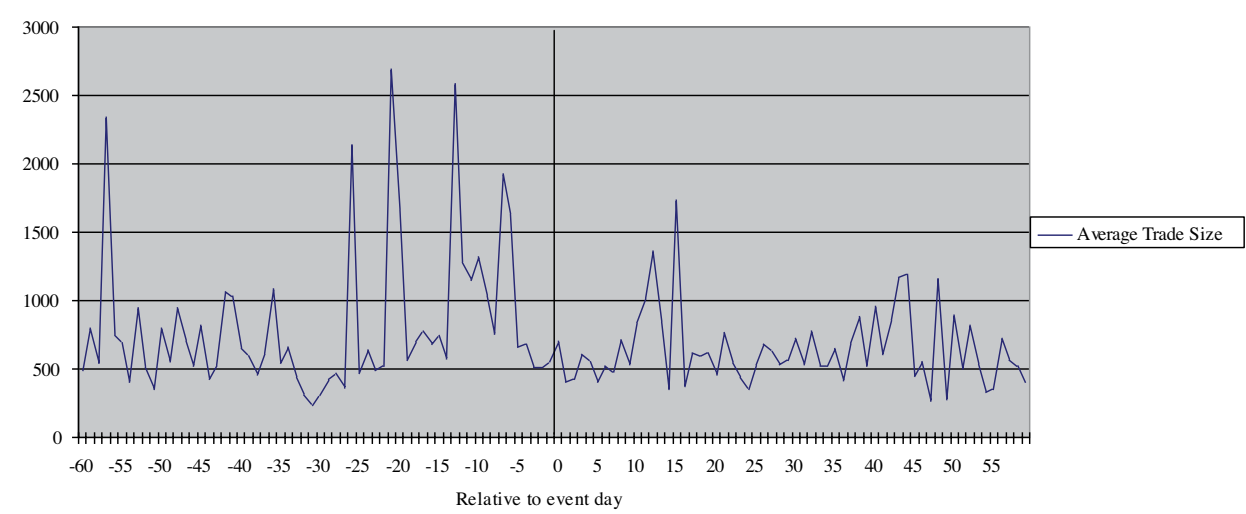


Graph 4

\section{Trading Volume}

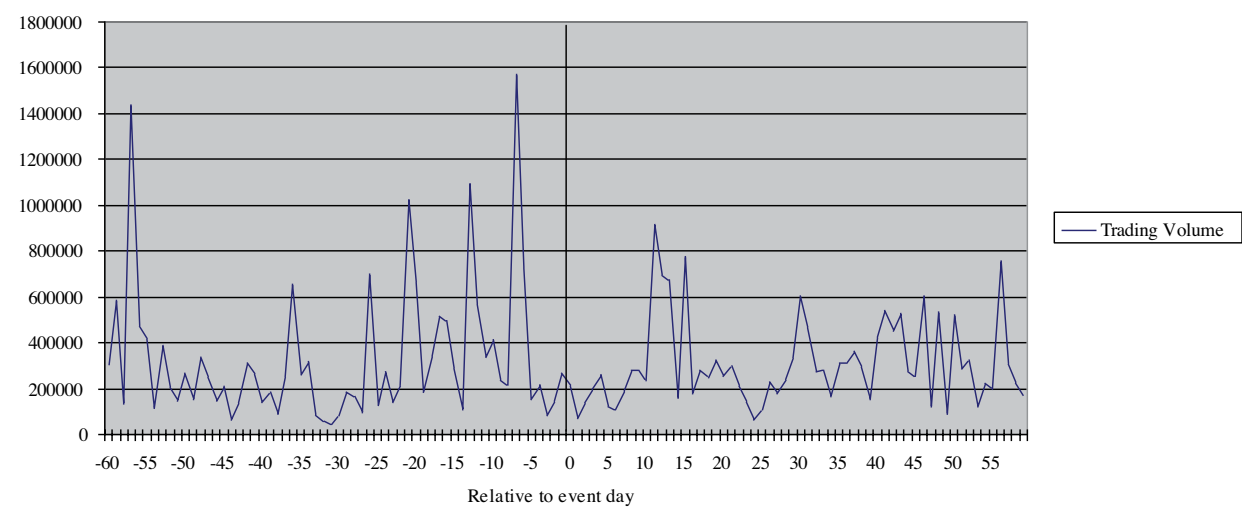

Table 1 shows that the number of trades increases by a statistically significant amount from 374 trades per day to 477 trades per day, yet average trade size and overall trading volume decrease but are not statistically significant except the average trade size variable (significant at $5 \%$ based on $\mathrm{T}$ statistics). A possible explanation for the decrease in trade size might be that traders shift from trading the underlying with large size to trading the option when it becomes available. In conclusion, we support our hypothesis 3 only for a liquidity measurement of number of trades, but not for trade size and trading volume variables.

Overall, these findings indicate a significant improvement in trading costs and the number of trades of TKC on the NYSE after the introduction of an option.

\section{Specific Results on Hypothesis 1: Impact on the Bid-Ask Spread}

In further analysis of the impact of options introduction on the bid-ask spread, we report the results of our regressions in Table 2, Panels A and B. Panel A reports results using relative quoted spread as the dependent variable in a step-wise regression to analyze the impact of trading characteristics on the spread. Panel B repeats the analysis using effective spread as the dependent variable.

The most outstanding result is that the dummy variable is negative and significant in all three regressions in both panels. This consistent result clearly indicates that the introduction of traded options reduces both the quoted and effective spreads. Additionally, the strength of the relationship (magnitude of the coefficient) increases in each threeregression set, even as additional variables are added to control for trade characteristics.

Looking at each regression in order, for Panel A, regression \#1, the dummy variable coefficient is negative and statistically significant as expected, confirming that the relative quoted spread decreases after option listing. Additionally, the number of trades is also negative but not significantly so while the volume coefficient is positive and significant at the 5\% level. The negative relationship between the spread and number of trades is consistent with McInish and Wood (1992). 
Table 2

\section{OLS Regression Analysis of Quoted and Effective Spread}

This table shows the step-wise regression results when spread measure is regressed against trading characteristic variables. In Panel A, the dependent variable (SPR) is the daily average relative quoted spread calculated as the difference of the bid and ask quotes scaled by the quote mid-point. In Panel B, the dependent variable $(E F F S P R)$ is the daily average relative effective spread calculated as the absolute difference between the transaction price and the quote mid-point scaled by the quote mid-point. Each variable is calculated for 30-minute 13 intervals for each day.

We estimate the following time series regression:

$S P R_{t}=\alpha+\beta_{1} D U M M Y_{t}+\beta_{2} L N T R A D E S_{t}+\beta_{3} L N V O L U M E_{t}+\beta_{4} S_{I G M A_{t}}+\beta_{5} L_{N P R I C E_{t}}+I_{N T T R D S}+$ $I N T V O L_{t}+I_{N T S I G M A_{t}}+I_{N T P R I C E_{t}}+\varepsilon_{t}$

The description of the variables provided below:

$D U M M Y: \quad 1$ for days after option listing day, 0 otherwise

LNTRADES: natural log of total number of trades

LNVOLUME: natural log of total trading volume

SIGMA: natural log of the difference between the percentage maximum midpoint quote price and the minimum midpoint quote price

LNPRICE: natural log of average trading price

INTTRDS: interaction variable for number of trades: DUMMY*LNTRADES

INTVOL: interaction variable for trading volume: DUMMY*LNVOLUME

INTSIGMA: interaction variable for volatility: $D U M M Y^{*} L N S I G M A$

INTPRICE: interaction variable for trading price: $D U M M Y^{*} L N P R I C E$

Panel A: Regressions with Relative Quoted Spread as dependent variable Dependent Variable: Relative Quoted Spread (SPR)

\begin{tabular}{|c|c|c|c|}
\hline Regression \# & (1) & $(2)$ & (3) \\
\hline Constant & $\begin{array}{l}0.294 * * * \\
(7.73)\end{array}$ & $\begin{array}{l}1.126 * * * \\
(24.05)\end{array}$ & \begin{tabular}{|l}
$2.041 * * *$ \\
$(14.33)$
\end{tabular} \\
\hline$D U M M Y$ & $\begin{array}{l}-0.1918^{* * * *} \\
(-3.31)\end{array}$ & $\begin{array}{l}-0.349 * * * \\
(-4.91)\end{array}$ & $\begin{array}{l}-1.379 * * * \\
(-6.02)\end{array}$ \\
\hline LNTRADES & \begin{tabular}{|l}
-0.058 \\
$(-5.23)$ \\
\end{tabular} & \begin{tabular}{|l}
$-0.087 * * *$ \\
$(-9.5)$ \\
\end{tabular} & $\begin{array}{l}-0.0849 * * * \\
(-9.41) \\
\end{array}$ \\
\hline LNVOLUME & $\begin{array}{l}0.014 * * \\
(2.41) \\
\end{array}$ & \begin{tabular}{|l|}
-0.002 \\
$(-0.60)$ \\
\end{tabular} & \begin{tabular}{|c|}
0.001 \\
$(0.22)$ \\
\end{tabular} \\
\hline SIGMA & & \begin{tabular}{|l|}
$0.103 * * *$ \\
$(23.57)$
\end{tabular} & \begin{tabular}{|l|}
$0.098^{* * * *}$ \\
$(22.40)$
\end{tabular} \\
\hline LNPRICE & & & \begin{tabular}{|l}
$-0.372 * * *$ \\
$(-7.01)$ \\
\end{tabular} \\
\hline INTTRDS & \begin{tabular}{|l|}
$0.036 * *$ \\
$(2.29)$ \\
\end{tabular} & \begin{tabular}{|l|}
$0.032 * *$ \\
$(2.47)$
\end{tabular} & \begin{tabular}{|l|}
$0.029 * *$ \\
$(2.30)$
\end{tabular} \\
\hline INTVOL & $\begin{array}{l}0.003 \\
(0.37) \\
\end{array}$ & \begin{tabular}{|l|}
0.006 \\
$(0.89)$ \\
\end{tabular} & \begin{tabular}{|l|}
0.0028 \\
$(0.39)$ \\
\end{tabular} \\
\hline INTSIGMA & & \begin{tabular}{|l|}
$-0.025 * * *$ \\
$(-4.00)$ \\
\end{tabular} & $\begin{array}{l}-0.0208^{* * * *} \\
(-3.26)\end{array}$ \\
\hline INTPRICE & & & \begin{tabular}{|l|}
$0.412^{* * * *}$ \\
$(5.10)$
\end{tabular} \\
\hline Number of Observations & 1554 & 1554 & 1544 \\
\hline Adjusted $R^{2}$ & 0.05 & 0.38 & 0.40 \\
\hline F-Value & $\begin{array}{l}18.08 \\
(\operatorname{Pr}<0.0001)\end{array}$ & \begin{tabular}{l|}
138.65 \\
$(\operatorname{Pr}<0.0001)$
\end{tabular} & $\begin{array}{l}116.66 \\
(\operatorname{Pr}<0.0001)\end{array}$ \\
\hline
\end{tabular}


Table 2 (continued)

Panel B: Regressions with Relative Effective Spread as dependent variable Dependent Variable: Relative Effective Spread (EFFSPR)

\begin{tabular}{|c|c|c|c|}
\hline Regression \# & (1) & (2) & (3) \\
\hline Constant & $\begin{array}{l}0.206^{* * *} \\
(7.73)\end{array}$ & $\begin{array}{l}0.762 * * * \\
(22.51)\end{array}$ & $\begin{array}{c}1.35 * * * \\
(13.47)\end{array}$ \\
\hline$D U M M Y$ & $\begin{array}{l}-0.136 * * * \\
(-3.31)\end{array}$ & $\begin{array}{l}-0.228 * * * \\
(-4.45) \\
\end{array}$ & $\begin{array}{l}-0.866^{* * *} \\
(-5.21) \\
\end{array}$ \\
\hline LNTRADES & $\begin{array}{l}-0.031^{* * * *} \\
(-5.63)\end{array}$ & $\begin{array}{l}-0.050^{* * * *} \\
(-7.61)\end{array}$ & $\begin{array}{l}-0.049 * * * \\
(-7.49)\end{array}$ \\
\hline LNVOLUME & $\begin{array}{l}0.007^{*} \\
(1.72)\end{array}$ & $\begin{array}{l}-0.004 \\
(-1.22)\end{array}$ & $\begin{array}{l}-0.001 \\
(-0.49) \\
\end{array}$ \\
\hline SIGMA & & $\begin{array}{l}0.0693 * * * \\
(21.76) \\
\end{array}$ & $\begin{array}{l}0.066^{* * * *} \\
(20.68) \\
\end{array}$ \\
\hline LNPRICE & & & $\begin{array}{l}-0.240^{* * * *} \\
(-6.25)\end{array}$ \\
\hline INTTRDS & $\begin{array}{l}0.016 \\
(1.44) \\
\end{array}$ & $\begin{array}{l}0.012 \\
(1.35) \\
\end{array}$ & $\begin{array}{l}0.011 \\
(1.19) \\
\end{array}$ \\
\hline INTVOL & $\begin{array}{l}0.005 \\
(0.94)\end{array}$ & $\begin{array}{l}0.007 \\
(1.49) \\
\end{array}$ & $\begin{array}{l}0.005 \\
(1.03) \\
\end{array}$ \\
\hline INTSIGMA & & $\begin{array}{l}-0.015^{* * * *} \\
(-3.39)\end{array}$ & $\begin{array}{l}-0.012 * * * \\
(-2.71)\end{array}$ \\
\hline INTPRICE & & & \begin{tabular}{|l|}
$0.256^{* * * *}$ \\
$(4.37)$ \\
\end{tabular} \\
\hline Number of Observations & 1554 & 1554 & 1544 \\
\hline Adjusted $R^{2}$ & 0.0039 & 0.34 & 0.36 \\
\hline F-Value & $\begin{array}{l}13.70 \\
(\operatorname{Pr}<0.0001)\end{array}$ & $\begin{array}{l}117.78 \\
(\operatorname{Pr}<0.0001)\end{array}$ & $\begin{array}{l}98.18 \\
(\operatorname{Pr}<0.0001)\end{array}$ \\
\hline
\end{tabular}

Notes: $1 . *, * *$, and $* * *$ denote significance at the $10 \%, 5 \%$, and $1 \%$ level, respectively.

Regression \#2 adds the volatility variable, measured by difference between the percentage maximum midpoint quote price and the minimum midpoint quote price during the 30-minute intraday interval, and the volatility interaction term as explanatory variables. The coefficient of volatility (SIGMA) is positive and significant at the $1 \%$ level, again, consistent with expectations, as high (low) volatility would increase (decrease) the bid-ask spread. Both the dummy variable and number of trades retain their appropriate sign and now both are significant at the $1 \%$ level. The volume variable is now also negative but has lost significance with the entrance of the volatility variable.

Regression \#3 adds price and the price interaction term as explanatory variables. Price is typically included as a control variable in cross-sectional analysis. Since we are studying time-series data for a single security, its interpretation in this construction is less clear. Interestingly, volume loses significance while volatility retains significance. As price becomes significant (and the coefficient negative) the dummy variable gains strength. In fact, with each step of the regression, the dummy variable gains strength. While these findings are consistent with Kim and Diltz (1991) in both sign and sig- 
nificance, the meaning of the price variable results is less obvious. Since we are using only one stock in this analysis and, over the span of the study, the price of the stock increased while the spread decreased, our results could simply reflect that change rather than a causal relationship.

Table 2, Panel B repeats the analysis described above, using effective spread as the dependent variable. The results are consistent with those for relative quoted spread in terms of sign and coefficient significance for all three regressions.

Focusing on the interaction terms in regression \#3 provides an analysis of the combined impact of option listing and other variables on the dependent variable, the bid-ask spread. Taking the dummy variable representing option listing as the focal variable, we define number of trades (TRDS), trade volume (VOL), volatility (SIGMA), and price (PRICE) as our moderator variables. All four of these along with their respective interaction variables are included in regression \#3 in both panels of Table 2.

By adding the coefficient of each interaction term to the coefficient of its related moderator variable we can determine whether the introduction of option trading results in the spread being more or less sensitive to that variable AFTER the option listing. These combinations and the resulting sensitivities are shown in Table 3, Panels A and B.

Table 3

\section{Analysis of Interaction Effects}

This table draws from the regression \#3 results shown in Table 2, Panels A and B. Column \#3 in each panel repeats the results from Table 2 . The +INT column combines the coefficient of each moderator variable with its associated interaction variable. The resulting sensitivity of the dependent variable (bid-ask spread) to this interaction is reflected in the SENS column by the direction of the arrows.

\begin{tabular}{|c|c|c|c|c|c|c|}
\hline & \multicolumn{3}{|c|}{ Panel A } & \multicolumn{3}{|c|}{ Panel B } \\
\hline & \multicolumn{3}{|c|}{ SPR } & \multicolumn{3}{|c|}{ ESPR } \\
\hline & \#3 & $+\mathrm{INT}$ & SENS & \#3 & $+\mathrm{INT}$ & SENS \\
\hline CONSTANT & 2.0410 & & & 1.3500 & & \\
\hline DUMMY & (1.3790) & & & $(0.8660)$ & & \\
\hline TRDS & $(0.0849)$ & $(0.0559)$ & $\downarrow$ & $(0.0490)$ & $(0.0380)$ & $\downarrow$ \\
\hline VOL & 0.0010 & 0.0038 & $\uparrow$ & $(0.0010)$ & 0.0040 & $\uparrow$ \\
\hline SIGMA & 0.0980 & 0.0772 & $\downarrow$ & 0.0660 & 0.0540 & $\downarrow$ \\
\hline PRICE & $(0.3720)$ & 0.0400 & $\Delta \downarrow$ & $(0.2400)$ & 0.0160 & $\Delta \downarrow$ \\
\hline INTTRDS & 0.0290 & & & 0.0110 & & \\
\hline INTVOL & 0.0028 & & & 0.0050 & & \\
\hline INTSIGMA & $(0.0208)$ & & & $(0.0120)$ & & \\
\hline INTPRICE & 0.4120 & & & 0.2560 & & \\
\hline ADJ R2 & 0.40 & & & 0.36 & & \\
\hline F-STAT & 116.66 & & & 98.18 & & \\
\hline
\end{tabular}


Results are consistent for both representations of the spread reported in Panels $\mathrm{A}$ and $\mathrm{B}$. The interaction of the dummy variable with number of trades (TRDS) and volatility (SIGMA) results in the spread being less sensitive to the moderator variable, demonstrated by the sum of the coefficients being smaller than the coefficient of the pure moderator variable. In the case of trade volume (VOL), the spread is more sensitive while the interaction of the dummy variable with price (PRICE) results in a change in the sign of the additive coefficient but with a smaller absolute magnitude.

\section{Conclusions}

In this study, we analyze the impact of the introduction of options on the market microstructure aspects of the underlying asset, the NYSE-traded Turkcell İletişim Hizmetleri A.Ş., (Turkcell) ADR, by studying changes in fundamental market liquidity variables before and after the option (TKC) listing.

We find that both daily relative quoted spreads and daily effective spreads decline after the option introduction. Our multivariate regression analysis with control variables for trade characteristics indicates that the introduction of traded options reduces both the quoted and effective spreads even after controlling number of trades, trade volume, and price. Additionally, we show that the number of trades increases by a statistically significant amount. This indicates improved liquidity after the option listing.

Return volatility, trade size and trading volume show no statistically significant change, counter to our hypothesized expectations. However, the standard deviations of average trade size and total trading volume decrease post-listing, indicating a more stabilized market.

Overall, we conclude that option trading improves the trading characteristics of the TKC ADR on the NYSE mainly by reducing trading costs while improving liquidity measured by number of trades.

Given the solid evidence of the benefits accruing to markets implementing trading in stock options, we believe our results, though limited to trading in one lightly traded option, can be extrapolated to support the positive impact stock options trading will have on related equity market efficiency as well as by attracting more foreign investment in Turkey. According to Saatçıoğlu, Karagül, and Volkan (2005: 45) in their conclusion, "Stock options allow investors, especially portfolio and fund managers, to participate in price movements without committing the large amount of funds needed to buy the stock outright and lead to more permanent and long-run foreign capital investment in the Istanbul Stock Exchange Stock market as foreign investors take advantage of this new hedging instrument."

Despite the significantly different market structures of the NYSE and the IMKB, we anticipate similar liquidity improvements, assuming informed traders from the IMKB take advantage of the opportunity to trade options. These implications are based on substantial theoretical and empirical evidence confirming the ability of options to complete the market for the underlying security, resulting in improved liquidity, without regard for the market structure of the trading venue. 


\section{References}

Anderson, A. and Dyl, E. (2005). "Market Structure and Trading Volume" Journal of Financial Research, 28(1): 115-131.

Arditti, F. and John, K. (1980). "Spanning the State Space with Options" Journal of Financial and Quantitative Analysis, 15: 1-9.

Bansal, V.K., Pruit, S., and Wei, K.C.J. (1989). "An Empirical Reexamination of the Impact of CBOE Option Initiation on the Volatility and Trading Volume of the Underlying Equities," Finance Review, 24: 19-29.

Bildik, R., (2004). "The Effects of Trading Halts and the Advantage of Institutional Investors: Evidence from the Istanbul Stock Exchange," Working paper, December.

Breeden, D. and Litzenberger, R. (1978). "Prices of State-contingent Claims Implicit in Option Prices," Journal of Business, 51: 621-652.

Calado, J.P.T., Garcia, M.T.M., and Pereira, S.E.T.M. (2005). "An Empirical Analysis of the Effects of Options and Futures Listing on the Underlying Stock Volatility: The Portuguese Case," Applied Financial Economics, 15: 907-913.

Chamberlain, T.W., Cheung, C.S., and Kwan , C.C.Y. (1993). "The Impact of Options Listing on Stock Behavior and Market Liquidity," Journal of Business Finance and Accounting, 20(5): 687-698.

Chaudhury, M. and Elfakhani, S. (1995). "The Volatility Effect of Options Listing: Some Canadian Experience," Quarterly Review of Economics and Finance, 35(1): 97-116.

Chen, D. and Chang, P. (2008). "The Impact of Listing Stock Options on the Underlying Securities: The Case of Taiwan, Applied Financial Economics, 18: 1161-1172.

Conrad, J. (1989). “The Price Effects of Option Introduction,” The Journal of Finance, 44(2): 487-498.

Damodaran, A. and Lim, J. (1991). "The effects of option listing on the underlying stocks return processes," Journal of Banking and Finance, 15(3): 647-664.

Danielsen, B.R. and Sorescu, S.M. (2001). "Why do Option Introductions Depress Stock Prices? A Study of Diminishing Short Sale Constraints," Journal of Financial and Quantitative Analysis, 36(4): 451-484.

DeTemple, J. and Jorion, P. (1990). "Option Listing and Stock Returns," Journal of Banking and Finance, 14(4): 781-801.

Fedenia, M. and Grammatikos, T. (1992). "Options Trading and the Bid-ask Spread of the Underlying Stocks,” Journal of Business, 65(3): 335-351.

Hakansson, N.H. (1978) "Welfare Aspects of Options and Supershares," The Journal of Finance, 33: 759-776.

Hayes, S.L. and Tennenbaum, M.E. (1979). "The Impact of Listed Options on the Underlying Shares," Financial Management, 8: 72-76.

Heer, B., Trede, M., and Wahrenburg, M. (1997). "The Effect of Option Trading at the DTB on the Underlying Stock's Return Variance," Empirical Economics, 22: 233-245.

John, K. (1981). "Efficient Funds in a Financial Market with Options: A New Relevance Proposition," Journal of Finance, 36: 385-395.

Jubinski, D. and Tomljanovich, M. (2007) "Options Listings and Individual Equity Volatility: A Survey," The Journal of the Futures Market, 27(1): 1-28. 
Kabir, R. (1999). "The Price and Volatility Effects of Stock Option Introduction: A Reexamination," Working paper, Tilburg University, Netherlands.

Kim S. and Diltz J.D. (1999). "The Effect of Option Trading on the Structure of Equity Bid/Ask Spreads," Review of Quantitative Finance and Accounting, 12: 395-413.

Kumar R., Sarin A., and Shastri K. (1998). "The Impact of Options Trading on the Market Quality of the Underlying Security: An Empirical Analysis," The Journal of Finance, 53 (2): 717-732.

Long D.M., Schinski M.D., and Officer D. (1994). "The Impact of Option Listing on the Price Volatility and Trading Volume of Underlying OTC Stocks," Journal of Economics and Finance, 18 (1): 89-100.

Ma, C.K. and Rao, R.P. (1988) "Information Asymmetry and Options Trading," The Financial Review, 23: 39-51.

Mayhew, S. and Mihov, V. T. (2005). "Short Sale Constraints, Overvaluation, and the Introduction of Options," (October 7, 2005). AFA 2005 Philadelphia Meetings. Available [online] at: SSRN: http:// ssrn.com/abstract $=544245$

Mazouz, K. and Bowe, M. (2009) "Does Option Listing Impact Time-varying Risk Characteristics of the Underlying Stocks? Evidence from NYSE Stocks Listed on the CBOE," Applied Financial Economics, 19: 203-212.

McInish, T. and Wood, R. (1992). "An Analysis of Intraday Patterns in Bid/ask Spreads for NYSE Stocks," The Journal of Finance, 47(2): 753-764.

Rao, R.P., Tripathy, N. and Dukes, W.P. (1991) "Dealer Bid-ask Spreads and Options Trading on Over-the-counter Stocks," Journal of Financial Research, 14: 317-325.

Saatçioğlu, E., Karagül, I., and Volkan, A. (2005). "Usefulness of Derivative Instruments in Emerging Markets: Turkish Experience," International Business and Economics Research Journal, 4(2): 37-46.

Sahlström P. (2001). "Impact of Stock Option Listing on Return and Risk Characteristics in Finland," International Review of Financial Analysis, 10(1): 19-36.

Schultz, P.H. and Zaman, M.A. (1991). "Option Introduction and the Underlying Stock's Trading Volume and Bid-ask Spread,” Working paper.

Shastri, K., Sultan, J., and Tandon, K. (1996). "The Impact of the Listing of Options in the Foreign Exchange Market," Journal of International Money and Finance, 15(1): 37-64.

Skinner, D.J. (1989) “Options Markets and Stock Return Volatility,” Journal of Financial Economics, 23(1): 61-78.

Sorescu, S. (2000). "The Effect of Options on Stock Prices: 1973-1995," Journal of Finance, 55: 487-514.

Stucki, T. and Wasserfallen, W. (1994). "Stock and Option Markets: The Swiss Evidence," Journal of Banking and Finance, 18: 881-893.

Watt, W.H., Yadav, P.K., and Draper, P. (1992). "The Impact of Option Listing on Underlying Stock Returns: The UK Evidence," Journal of Business Finance and Accounting, 19: 485-503.

Whiteside, M.M., Duke, W.P., and Dunne, P.M. (1983). "Short Term Impacts of Option Trading on Underlying Securities," Journal of Financial Research, 6 (Winter): 313-321.

Yip, Y. and Lai, M. (2009). "Impact of Warrant Listings on Its Underlying Stocks: The Malaysian Evidence," Academy of Accounting and Financial Studies Journal, 13(3): 107-121. 